УдК 663.1

\title{
EXPERIMENTAL INVESTIGATIONS OF ALCOHOL DESORPTION PROCESSES FROM WATER SOLUTIONS
}

\author{
A. Sokolenko, O. Shevchenko, O. Stepanets \\ National University of Food Technologies
}

\begin{tabular}{l} 
Key words: \\
Fermentation \\
Distillation \\
Ethyl alcohol \\
Solubility \\
Desorption \\
Condensation \\
Henry's law \\
\hline
\end{tabular}

Article history:

Received 09.11.2018

Received in revised form

27.11.2018

Accepted 18.12.2018

Corresponding author:

A. Sokolenko

E-mail:

npnuht@ukr.net

\begin{abstract}
The paper outlines the results of the generalization and study of the experience in evaluating the causes and levels of the effects of physical-chemical factors due to the limitation of the concentrations of synthesized alcohol under conditions of anaerobic digestion of sugar-containing media. Among the latter are the total osmotic pressure of dissolved $\mathrm{C}_{2} \mathrm{H}_{5} \mathrm{OH}$ and $\mathrm{CO}_{2}$, as well as the saturation of the liquid fraction of media with carbon dioxide. It is shown that the latter leads to a sharp increase in the resistance of mass transfer on the boundary between fraction separation between yeast cells and the medium.

Comparison of these two factors leads to the conclusion that osmotic pressure of $\mathrm{CO}_{2}$ is limited by the solubility of its gas fraction in the ratio of 1: 8 with alcohol, therefore it is proposed to use technology in which the concentration of $\mathrm{C} 2 \mathrm{H} 5 \mathrm{OH}$ is expedient to use at subcritical levels up to $6 \%$ vol.

The paper assesses the possibilities of such restrictions by combining fermentation and distillation under vacuum, or by removing alcohol with activated stream of $\mathrm{CO}_{2}$ using alcoholic absorbers, or by purging the medium with inert gas with the introduction of forced circulation and condensation of steam fractions.

The direction of limiting the effects of saturation media on $\mathrm{CO}_{2}$ is proposed on the basis of transient processes with desaturation due to variables and regulated pressures in the gas ingenious fraction in accordance with Henry's law.

The presence of effects on the alcohol desorption level of the temperature of the medium is shown, and the efficiency of the processes is proposed to be carried out on the basis of measurements of the concentrations of alcohol in the condensate.

Information about the arrangement of a laboratory equipment, which uses the modes of desorption of ethyl alcohol by dispersed air and carbon dioxide flows, as well as the theoretical positions of desorption processes are given. The prospect of achieving subcritical fermentation regimes and the scheme of designing a system for extracting wateralcohol condensate from the vapor-gas stream of $\mathrm{CO}_{2}+$ $+\mathrm{C}_{2} \mathrm{H}_{5} \mathrm{OH}$ have been proven.
\end{abstract}

DOI: $10.24263 / 2225-2924-2018-24-6-14$ 


\title{
ЕКСПЕРИМЕНТАЛЬНІ ДОСЛІДЖЕННЯ ПРОЦЕСІВ ДЕСОРБЦІЇ СПИРТУ З ВОДНИХ РОЗЧИНІВ
}

\author{
А.І. Соколенко, О.Ю. Шевченко, О.І. Степанець \\ Начіональний університет харчових технологій
}

У статті викладено результати узагальнення $i$ вивчення досвіду оцінки причин $і$ рівнів впливів фізико-хімічних факторів у зв'язку з обмеженнями конщентрацій синтезованого спирту в умовах анаеробного зброджування иукровмісних середовищ. До числа останніх віднесено сумарні осмотичні тиски розчинених $\mathrm{C}_{2} \mathrm{H}_{5} \mathrm{OH}$ i $\mathrm{CO}_{2}$, а також насиченість рідинної фракцї середовищ діоксидом вуглеию. Показано, щчо останнє приводить до різкого підвищення опору масопередачі на межі поділу фракиій між дріжджовими клітинами і середовищем.

Порівняння ичих двох факторів приводить до висновку про те, щзо осмотичні тиски $\mathrm{CO}_{2}$ обмежуються розчинністю його газової фракції у співвідношенні 1:8 зі спиртом, тому пропонуються до використання технології, за яких концентрації $\mathrm{C}_{2} \mathrm{H}_{5} \mathrm{OH}$ доцільно використовувати на докритичних рівнях в межах до 6\%об.

Оиінюються можливості таких обмежень за рахунок суміщення бродіння $i$ перегонки під вакуумом, або за рахунок відбирання спирту активованим потоком $\mathrm{CO}_{2}$ з використанням спиртовловлювачів, або продуванням середовища інертним газом з влаштуванням примусової цүиркуляції $і$ конденсащіі парових фракиій.

Напрямок з обмеження впливів явищ насичення середовищ на $\mathrm{CO}_{2}$ пропонується на основі перехідних прочесів з десатурацією за рахунок змінних $i$ регульованих тисків у газовій надрідинній фракції відповідно до закону Генрі.

Показано наявність впливів на рівень десорбиіі спирту температури середовища, а результативність процесів запропоновано здійснювати на основі вимірів концентрацій спирту в конденсаті.

Наведено інформацію щчодо облаштування лабораторної установки, на якій реалізовано режими десорбиї етилового спирту диспергованими потоками повітря $і$ діоксиду вуглецю, а також теоретичні положення процесів десорбиії. Доводиться перспективність досягнення докритичних режимів бродіння і схема оформлення системи для вилучення водно-спиртового конденсату з парогазового потоку $\mathrm{CO}_{2}+\mathrm{C}_{2} \mathrm{H}_{5} \mathrm{OH}$.

Ключові слова: бродіння, перегонка, етиловий спирт, розчинність, десорбція, конденсація, закон Генрі.

Постановка проблеми. Попередні теоретичні узагальнення і вивчення досвіду показують наяність двох факторів впливу, які визначають обмеження анаеробного бродіння з точки зору накопичення етилового спирту. Очевидно, що це концентрації самого $\mathrm{C}_{2} \mathrm{H}_{5} \mathrm{OH}$ i $\mathrm{CO}_{2}$, впливи яких проявляються через осмотичні тиски в сумарній дії (принцип суперпозиції) [1-3]. Однак впливи цих двох складових нерівноважні, оскільки розчинність $\mathrm{CO}_{2}$ обмежується 
відповідно до закону Генрі. Так, концентрація спирту становить $8 . .10 \%$ об., що відповідає $80 \ldots 100$ мл/л, а масова концентрація - $64 \ldots 80$ г/л. Масова концентрація $\mathrm{CO}_{2}$ може досягати $8 . .10$ г/л. Їх співвідношення становить:

$$
\frac{64 \ldots 80}{8 \ldots 10} \approx 8 \text {. }
$$

За значень відомих молекулярних мас $\mathrm{C}_{2} \mathrm{H}_{5} \mathrm{OH}$ та $\mathrm{CO}_{2} 46 / 44=1,046$ співвідношення їх максимальних осмотичних тисків складає близько 7,7 одиниці. Це означає, що головним напрямком впливу на систему $є$ виведення з середовища $\mathrm{C}_{2} \mathrm{H}_{5} \mathrm{OH}$. Проте останнє суперечить початковому завданню процесу бродіння [4-6], а тому потрібно вирішити цю внутрішню суперечність, наприклад, за рахунок:

- суміщення бродіння і перегонки під вакуумом [7; 8];

- відбирання спирту з активованим потоком $\mathrm{CO}_{2} 3$ використанням спиртовловлювачів [9; 10];

- продуванням середовища інертним газом з влаштуванням примусової циркуляції і конденсації.

Другий напрямок - дестабілізація системи з переведенням ії до перехідних процесів за рахунок змін тисків у газовій фазі. Це дає можливість нівелювати опір масопередачі по $\mathrm{CO}_{2}$ за показниками насичених середовищ.

Використання названих заходів щодо обмеження концентрацій спирту в розчинах на докритичних для дріжджів показниках потребує експериментальної перевірки, хоча відомий факт вилучення частини $\mathrm{C}_{2} \mathrm{H}_{5} \mathrm{OH}$ діоксидом вуглецю вказує на таку можливість $[11 ; 12]$.

Мета дослідження: оцінити перспективи застосування технологій 3 докритичними режимами анаеробного зброджування цукровмісних середовищ.

Методи дослідження: феноменологічні узагальнення теорії десорбції етилового спирту з експериментальною оцінкою ії результатів на основі термодинамічних законів і закономірностей гідродинаміки газорідинних середовищ та розчинності.

Результати i обговорення. Феноменологічні міркування призводять до висновку про те, що загальний результат залежить від інтенсивності вхідного газового потоку, геометрії середовища у співвідношенні площі його перерізу і висоти, концентрації алкоголю в рідинній фракції і температури. Параметри вхідного газового потоку і площі поперечного перерізу середовища на основі розрахункової величини приведеної швидкості дають змогу моделювати середовище по гідродинамічному стану. При цьому значення має і висота середовища, вплив якої залежить від ії абсолютного значення і розмірів бульбашок диспергованої газової фракції та глибини занурення диспергатора.

Установка складається (рис. 1) 3 моделі масообмінного апарата у формі мірного циліндра 1 місткістю 1 л, конденсатора 2, виконаного за формою усіченого конуса, 3 охолоджувальною водою у суміші 3 подрібненим льодом, збірника 3 конденсату з геометрією, що відповідає конденсатору, але доповненого отворами для пропускання сумішей газової і парових фракцій. Контактування останніх 3 поверхнею конденсатора приводить до утворення рідинної фракції і збирання іiї в нижній частині збірника 3. Величина газового потоку, що 
вводиться в середовище, контролюється ротаметром 7, а концентрація спирту в конденсаті визначається рефрактометром.

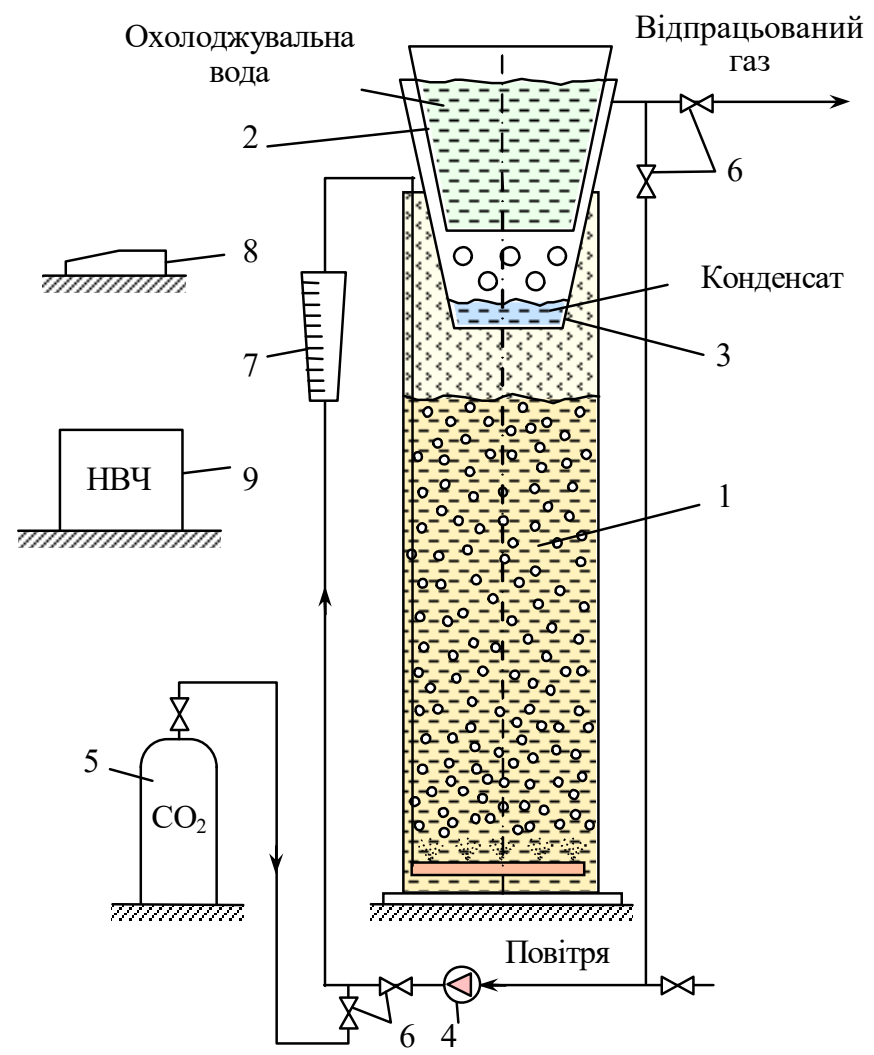

Рис. 1. Схема лабораторної установки для оцінки десорбції $\mathrm{C}_{2} \mathrm{H}_{5} \mathrm{OH}$ диспергованою газовою фракцією: 1 - модель масообмінного апарата;

2 - конденсатор; 3 - збірник конденсату; 4 - мінікомпресор; 5 - балон із $\mathrm{CO}_{2}$; 6 - запірна арматура; 7 - ротаметр; 8 - рефрактометр REF 503/513; 9 - HBЧ нагрівач

Початкова концентрація $\mathrm{C}_{2} \mathrm{H}_{5} \mathrm{OH}$ задавалася в межах 6...8\%об. 3 додатковим контролем рефрактометром.

У результаті масообміну з рідинною фракцією кожна газова бульбашка стає носієм парової фракції у складі $\mathrm{H}_{2} \mathrm{O}$ та $\mathrm{C}_{2} \mathrm{H}_{5} \mathrm{OH}$ і 3 врахуванням $\mathrm{CO}_{2}$ маємо сукупність:

$$
\text { діоксид вуглецю + вода + етиловий спирт }
$$

або

$$
\text { повітря + вода + етиловий спирт. }
$$

Пропускання таких парогазових сумішей через конденсатор приводить до конденсації $\mathrm{H}_{2} \mathrm{O}$ і $\mathrm{C}_{2} \mathrm{H}_{5} \mathrm{OH}$, а газова фракція в режимі циркуляції повертається в диспергатор у випадку промислового використання такої системи.

У лабораторних дослідженнях відпрацьоване повітря переходить у навколишнє середовище, а діоксид вуглецю рециркулює в системі. 
Контролю підлягали концентрації спирту в середовищі і в конденсаті. У зв'язку з обмеженістю часу проведення кожного досліду зміни концентрацій у середовищі малопомітні, тоді як вимір вмісту спирту в конденсаті позбавлений цього недоліку.

Утворення парових фракцій $\mathrm{H}_{2} \mathrm{O}$ і спирту в газових бульбашках пов'язано 3 відповідними енергетичними витратами, інтенсивність і спрямованість яких залежать від температури рідинної фракції. У зв'язку з цим інтенсивність вилучення спирту визначалася за змінних температур і за інших рівних умов. Запланована на кожний дослід температура досягалася в дискретному режимі за використання НВЧ-нагрівача 9.

Узагальнені результати цієї частини досліджень наведені в табл. 1 та на графіку (рис. 2) за витрат газової фракції 0,4 л/хв і концентрації спирту в рідинній фракції 6\%об.

Таблиця 1. Залежність концентрації спирту (\%об.) в конденсаті від температури розчину

\begin{tabular}{|c|c|c|c|c|c|c|c|c|}
\hline $\begin{array}{c}\text { Температура } \\
\text { розчину, }{ }^{\circ} \mathrm{C}\end{array}$ & 20 & 25 & 30 & 35 & 40 & 45 & 50 & 55 \\
\hline $\begin{array}{c}\text { Концентрація } \\
\text { спирту, \%об. }\end{array}$ & 14,15 & 17,36 & 22,5 & 17,64 & 34,1 & 40,2 & 45,0 & 48,9 \\
\hline
\end{tabular}

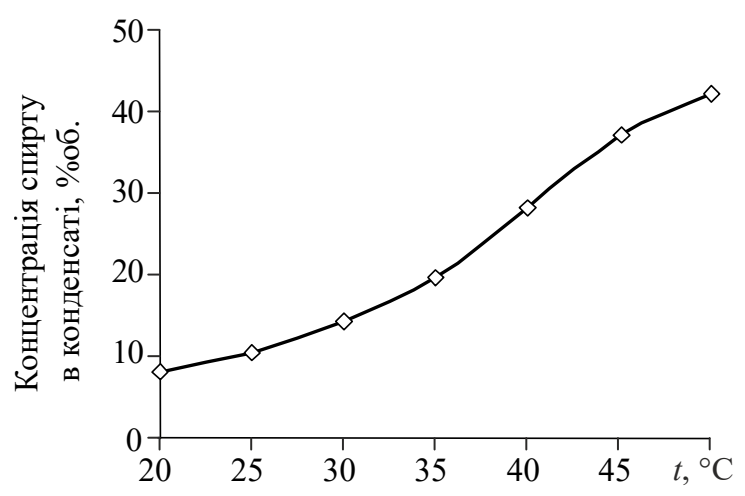

Рис. 2. Графічна інтерпретація залежності концентрації спирту в конденсаті від температури розчину

При діаметрі циліндра $d=60$ мм значення приведеної швидкості газової фази складає:

$$
w_{\text {пр }}=\frac{Q_{\max }}{f}=\frac{0,0067 \cdot 10^{-3}}{0,002826}=0,00237 \mathrm{~m} / \mathrm{c} .
$$

Результати цієї частини досліджень показують, що процеси масообміну на рівні десорбції спирту з середовища відповідають принципу Ле Шательє, за яким підвищення температури і зниження тиску сприятливі для цих процесів. Вони значною мірою залежать від фізико-хімічних властивостей рідинної і газової фаз, геометричних параметрів десорбера, інтенсивності потоку диспергованої газової фази тощо. 


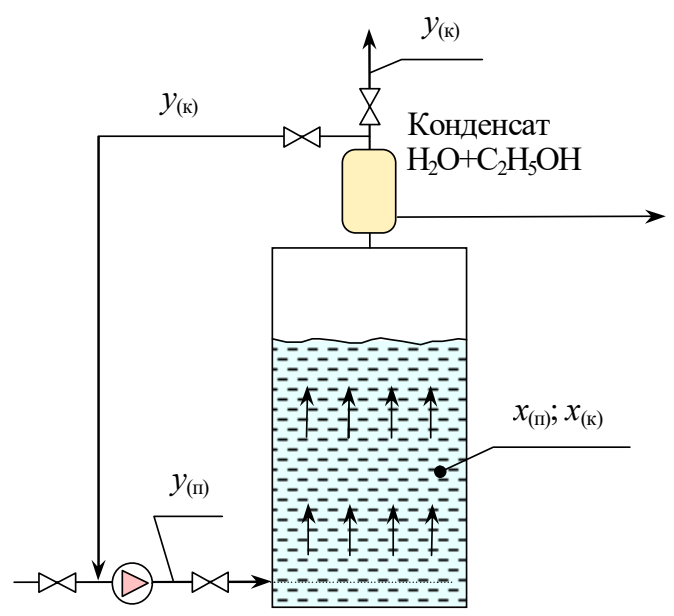

Рис. 3. Схема до визначення потоків десорбера

Дослід, у якому роль сорбенту виконана повітрям, відповідає незамкненій системі (рис. 3) з вилученням відпрацьованого повітря в довкілля. Концентрацію спирту в газовому потоці позначимо, відповідно, початкову і кінцеву $y_{(\text {п) }}$ та $y_{(\kappa)}$, а в рідинній фракції, відповідно, $-x_{(\text {п) }}$ та $x_{(\kappa)}$. Тоді матеріальний баланс відобразиться залежністю:

$$
M_{\text {г.п. }}\left(y_{(\kappa)}-y_{(\text {п) }}\right)=M_{\text {рід. }}\left(x_{(\text {п) }}-x_{(\text {к) }}\right),
$$

а необхідна величина газового потоку через середовище при $y_{(\text {п) }}=0$ складе:

$$
M_{\text {г.п. }}=M_{\text {рід. }} \frac{x_{(\text {п) }}-x_{(к)}}{y_{(\kappa)}},
$$

де $M_{\text {г.п. }}$ і $M_{\text {рід. }}$ - відповідно, масові потоки газової і рідинної фракцій; для випадку, коли роль десорбера виконує безпосередньо бродильний апарат, $M_{\text {рід. }}$ і $M_{\text {г.п. }}$ - відповідно, маси рідинної та пропущеної газової фракцій.

За випадку замкнутої системи отримаємо:

$$
M_{\text {г.п. }}=M_{\text {рід. }} \frac{x_{(\text {п) }}-x_{(\text {к })}}{y_{(\text {к) }}-y_{(\text {п) }}} .
$$

Якщо не враховувати можливих втрат спирту, то його кількість, що передається з рідинної фази в газову, складає:

$$
M_{\text {сп. }}=M_{\text {г.п. }}\left(y_{(\text {к })}-y_{(\text {п) }}\right)=M_{\text {рід. }}\left(x_{(\text {п) }}-x_{(\text {к) }}\right) .
$$

Питомі витрати газової фракції:

$$
\frac{M_{\text {г.п. }}}{M_{\text {рід. }}}=m=\frac{x_{(\text {п) }}-x_{(\kappa)}}{y_{(\text {к) }}-y_{(\text {п) }}} .
$$


Рівняння (2) є рівнянням прямої лінії, побудованої в прямокутній системі координат Оуx. На рис. 4 ця лінія позначена як відрізок АВ, кутовий коефіцієнт якого визначається рівнянням:

$$
\operatorname{tg} \alpha=m=\frac{x_{(\text {п) }}-x_{(\text {к })}}{y_{(\text {к })}-y_{(\text {п) }}} .
$$

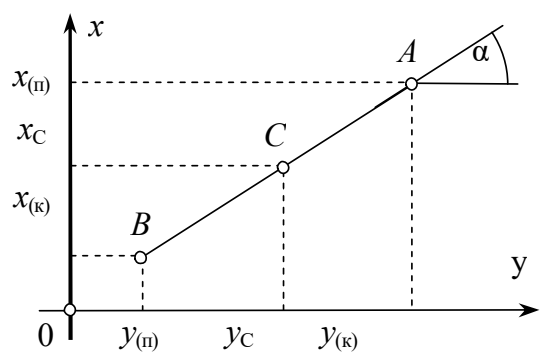

Рис. 4. Робоча лінія десорбера

Наведені залежності відповідають випадку проточного десорбера, який може бути створений як надбудова до бродильного апарата. Для випадку, коли сам бродильний апарат виконує цю роль, бажаним є створенням газового циркуляційного контуру. Внизу, у висхідній частині останнього встановлюється газорозподільний пристрій, а початковій концентрації спирту в середовищі має відповідати умова:

$$
x_{(\text {п) }} \leq x_{\text {кр }}, \mathrm{\kappa г} / \mathrm{M}^{3},
$$

де $x_{\text {кр }}$ - критична концентрація спирту, визначена для умови бродіння.

Очевидно, що за таких умов величина газового потоку має відповідати масовому потоку синтезу спирту:

$$
M_{\text {г.п. }}=\frac{M_{\text {рід. }}^{\prime}}{y_{(\text {к })}-y_{(\text {п) }}} \cdot \frac{d m_{\mathrm{C}_{2} \mathrm{H}_{5} \mathrm{OH}}}{d t},
$$

де $d m_{\mathrm{C}_{2} \mathrm{H}_{5} \mathrm{OH}} / d t-$ швидкість синтезу спирту в одиниці об'єму середовища, $\kappa \Gamma /\left(\mathrm{c} \cdot \mathrm{M}^{3}\right)$.

Вибір газової фракції має стосуватися інертного середовища. Для анаеробних умов це може бути діоксид вуглецю, хоча використання азоту в герметичних системах сприяло б обмеженню негативних впливів по $\mathrm{CO}_{2}$. Однак безперервний синтез останнього в кінцевому результаті привів би до витіснення $\mathrm{N}_{2}$ з системи. У зв'язку з цим і з урахуванням перспектив стабілізації концентрацій спирту на докритичних умовах в промислових бродильних апаратах група наступних дослідів стосувалася оцінки можливостей десорбції етилового спирту в замкнутому контурі на основі діоксиду вуглецю. Після заповнення системи $\mathrm{CO}_{2}$ вона герметизувалася і досліди повторювалися за попередньо зазначених температур. Узагальнені на основі статистичної обробки результати наведені в табл. 2. 
Одержані результати підтверджують можливість реалізації стабілізації середовищ на докритичних рівнях концентрацій у них $\mathrm{C}_{2} \mathrm{H}_{5} \mathrm{OH}$. При цьому інтенсивність десорбції спирту помітно залежить від температури і зростає зі збільшенням останньої.

Таблиця 2. Результати досліджень по оцінці десорбції етилового спирту діоксидом вуглецю в замкнутому циркуляційному контурі за концентрації $\mathrm{C}_{2} \mathrm{H}_{5} \mathrm{OH}$ в розчині 6\% об.

\begin{tabular}{|c|c|c|c|c|c|c|c|}
\hline Tемпература середовища, ${ }^{\circ} \mathrm{C}$ & 20 & 25 & 30 & 35 & 40 & 45 & 50 \\
\hline $\begin{array}{c}\text { Концентрація спирту в } \\
\text { конденсаті, \% об. }\end{array}$ & 8,5 & 11 & 15 & 20,2 & 29 & 38,1 & 49,2 \\
\hline
\end{tabular}

Однак збільшення температур культуральних середовищ обмежується умовами існування дріжджових культур, для яких оптимальним умовам відповідають $28 . . .32^{\circ} \mathrm{C}$. Термотолерантні дріжджі Saccharomyces cerevisiae раси XII-T та k-81 витримують температури $36 \ldots 37^{\circ} \mathrm{C}$, а дріжджі Schizosaccharomyces pombe 80 - до $33 \ldots 34^{\circ} \mathrm{C}$.

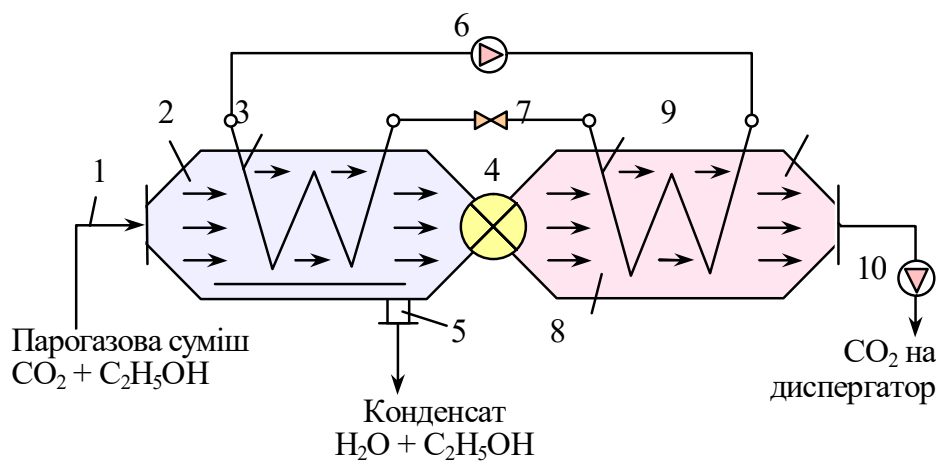

Рис. 5. Схема системи для вилучення водно-спиртового конденсату 3 парогазового потоку $\mathrm{CO}_{2}+\mathrm{C}_{2} \mathrm{H}_{5} \mathrm{OH}$

Названі культури мікроорганізмів відносяться до осмофільних, вони стійкі до спирту і можуть накопичувати його до $12 . .13 \%$, а тому для них можливо призначати критичні концентрації на рівні 7...8\% об. як фактор інтенсифікації десорбції. Іншим і найменш обмеженим за величиною $є$ фактор інтенсивності диспергованого газового потоку, який підлягає термодинамічним трансформаціям у зв'язку 3 необхідністю конденсації і виділення 3 потоку $\mathrm{H}_{2} \mathrm{O}$ та $\mathrm{C}_{2} \mathrm{H}_{5} \mathrm{OH}$. Охолодження парогазового потоку має здійснюватися в конденсаторі $з$ наступним підвищенням температури в енергетичному рекуператорі. Схема такої комбінації наведена на рис. 5. Відповідно до неї потік 1 парогазової суміші потрапляє в конденсатор 2 і в результаті взаємодії з поверхнею охолодження випарника 3 теплового насоса суміш охолоджується 3 виділянням конденсату $\mathrm{H}_{2} \mathrm{O}$ i $\mathrm{C}_{2} \mathrm{H}_{5} \mathrm{OH}$. Режим проходження потоку в конденсаторі регулюється шлюзовим затвором 4, а видалення конденсату $\mathrm{H}_{2} \mathrm{O}+$ $+\mathrm{C}_{2} \mathrm{H}_{5} \mathrm{OH}$ здійснюється через регулювальний клапан 5. Парова фракція холодильного агента відсмоктується з випарника компресором 6, стискається 
в адіабатному режимі 3 підвищенням температури і передається в конденсатор 7 рекуператора 8. Взаємодія холодного потоку $\mathrm{CO}_{2} 3$ поверхнею нагрівання конденсатора приводить до підвищення номінальної температури вихідного потоку $9 \mathrm{CO}_{2}$, який компресором 10 спрямовується на диспергатор у бродильний апарат. Конденсат суміші $\mathrm{H}_{2} \mathrm{O}$ i $\mathrm{C}_{2} \mathrm{H}_{5} \mathrm{OH}$ передається на перегонку або в проміжний накопичувач. Стабілізація концентрації спирту на докритичному рівні забезпечує подальше бродіння з номінальними технологічними умовами. Числове значення концентрації спирту, що відповідає докритичному режиму, одночасно означає показник осмотичного тиску, за якого середовище знаходиться на стадії активного бродіння. Підтримання при цьому на номінальному рівні концентрації цукрів забезпечить подовження такого бродіння i підвищення продуктивності синтезу $\mathrm{C}_{2} \mathrm{H}_{5} \mathrm{OH}$. Проте наявність у середовищі сторонньої мікрофлори 3 пришвидшеним приростом біомаси приводить до необхідності заміни культурального середовища, а тому в стадії доброджування раціональним є перевищення показника критичної концентрації спирту до максимально можливої.

Безперервний режим десорбції спирту і стабілізація його концентрації на заданому показнику означає баланс в цьому процесі з його синтезом. Порушення такого балансу можливе як у бік зменшення, так і в бік збільшення, проте для реалізації технології анаеробного бродіння життєдіяльність дріжджів бажано підтримувати також на найвищому рівні. За таких умов система стабілізації концентрації спирту повинна забезпечувати виконання умов:

$$
c_{\mathrm{c}(\min )}<c_{\mathrm{c \Pi}(i)} \leq c_{\mathrm{cп}(\mathrm{\kappa p})},
$$

де $c_{\text {сп }(i)}$ - плинна концентрація спирту; $c_{\text {сп(min) }}$ - мінімальна концентрація спирту, за якої стає доцільною робота системи стабілізації; $c_{\text {сп(кр) }}-$ критична концентрація розчиненого спирту в середовищі.

Досягнення останньої умови можливе за рахунок керованої інтенсивності циркуляційного контуру роботи компресора 10 з регульованою продуктивністю. Це означає необхідність оснащення системи засобами контролю концентрації спирту безпосередньо в культуральному середовищі, в конденсаті та температури суміші на вході в конденсатор контролером.

Наявність диспергатора газової фракції означає можливість потужного впливу на гідродинамічний режим середовища та інтенсивність масообмінних процесів, що визначається як позитивний фактор впливу на систему. Разом з тим використання в системі діоксиду вуглецю означає, що у висхідній частині циркуляційного газорідинного контуру рідинна фракція буде знаходитися в стані насичення і перенасичення на $\mathrm{CO}_{2}$. Це створює перепони масопередачі по $\mathrm{CO}_{2}$ на поверхні між дріжджовими клітинами і середовищем. Для ліквідації такого ускладнення доцільним $є$ використання змінних тисків у газовому надрідинному середовищі на рівні доповнення до цісї системи.

\section{Висновки}

Виконані теоретичні узагальнення щодо особливостей процесів анаеробного зброджування цукровмісних середовищ і експериментальна перевірка окремих положень дають змогу зазначити: 
1. Можливості створення докритичних режимів анаеробного бродіння 3 концентраціями спирту в межах до 6\%об. стосуються поєднання процесів бродіння і вакуумної перегонки.

2. Режими десорбції спирту з культуральних середовищ можуть бути реалізовані за рахунок активованих газорідинних циркуляційних контурів на основі $\mathrm{CO}_{2}$ iз застосуванням процесів конденсації пари $\mathrm{H}_{2} \mathrm{O}$ i $\mathrm{C}_{2} \mathrm{H}_{5} \mathrm{OH}$ в спиртовловлювачах-кондесаторах.

3. Результативність десорбції спирту залежить від величин інтенсивності газових потоків, геометрії бродильних апаратів (середовищ) і значень температур.

4. Доцільним у нових технологіях бродіння є поєднання десорбції спирту з рідинної фракції і стабілізація концентрації $\mathrm{C}_{2} \mathrm{H}_{5} \mathrm{OH}$ на докритичних значеннях та десатурації середовищ.

\section{Література}

1. Динаміка перехідних процесів в системах анаеробного бродіння / Шевченко О.Ю., Соколенко А.І., Степанець О.І. та ін. Наукові прайі Найінального університету харчових технологій. 2017. Том 23, № 6. С. 68-76.

2. Анаеробне бродіння в екстремальних режимах / Соколенко А.І., Шевченко О.Ю., Степанець О.І. та ін. Наукові прайі Наџџонального університету харчових технологій. 2018. Том 24, № 4. C. 146-153.

3. Intensification of energy and mass exchange processes in fermentation technologies: monograph / Sokolenko A., Shevchenko O., Vasylkivskyi K. and ot. Pleven: Mediateh, 2018. P. 145.

4. Шевченко О.Ю., Соколенко А.І., Вінніченко І.М. Особливості масообмінних процесів в анаеробних газорідинних середовищах Наукові праиі Національного університету харчових технологій. 2018. Том 24, № 5. С. 124-134.

5. Buera P., Charle G. (1994), Water activity, glass transition and microbial stability in concentrated. Cemimoist Food system G. Food Sci., 59. P. 921-927.

6. Пирог Т.П. Загальна біологія. Київ: НУХТ, 2010. 632 с.

7. Система зброджування сусла у виробництві етанолу: патент на винахід 103440 Україна: C12G 3/10 (2006.01), B01D 3/10 (2006.01), C12C 7/22 (2006.01) / Соколенко А.І., Піддубний В.А., Максименко І.Ф.; власник НУХТ. № а201212910; заявл. 13.11.2012; опубл. 10.10.2013, Бюл. № 18.

8. Бродильний апарат: патент на винахід 107407 Україна: C12F 3/08 (2006.01) / Чагайда А.О., Піддубний В.А., Соколенко А.І., Пімінова Г.А.; власник НУХТ. № а201305631; заявл. 30.04.2013; опубл. 25.12.2014, Бюл. № 24.

9. Бродильний апарат: патент на корисну модель 80311 Україна: C12F 3/08 (2006.01) / Піддубний В.А., Коваль О.В., Максименко І.Ф.; власник НУХТ. № u201212920; заявл. 13.11.2012; опубл. 27.05.2013, Бюл. № 10.

10. Бродильний апарат: патент на винахід 104401 Україна: C12F 3/08 (2006.01), C12M 1/00/ Криворотько В.М., Соколенко А.І., Максименко І.Ф., Бойко О.О.; власник НУХТ. № а201305632; заявл. 30.04.2013; опубл. 27.01.2014, Бюл. № 2.

11. Шиян П.Л., Сосницький В.В., Олійнічук С.Т. Інноваційні технології спиртової промисловості. Теорія і практика: монографія. Київ: ВД «Асканія», 2009. 424 с.

12. Технологія спирту: підручник / В.О. Маринченко, В.А. Домарецький, П.Л. Шиян та ін. Вінниця: «Поділля-2000», 2003. 496 с. 